\title{
FLEXIBILITY OF MECHANICAL BIOLOGICAL TREATMENT PLANTS
}

\author{
Bojan Plavac, Igor Sutlović, Veljko Filipan
}

Subject rewiew

Mechanical Biological Treatment (MBT) of waste represents a series of mechanical and biological processes which have the purpose to reduce the amount of waste that is placed on a landfill. In accordance to the 'hierarchy of waste' defined by the EU Waste Framework Directive, waste disposal to landfill represents the least desirable option.Considering the MBT process, the input component is a Municipal Solid Waste (MSW) and output components consist of Refuse Derived Fuel (RDF), compost and possibly the materials suitable for recycling. The quality of output components depends on the input waste composition.More efficient primary waste separation decreases capacity and complexity of MBT facilities.RDF offers possibility of energy recovery from the part of such separated fractions.MBT technology does not solve the problem of harmful substances residual in MSW narrowing the application of compost obtained by the biological treatment and requiring additional treatment of flue gases from RDF combustion. Comparison of the composition of untreated MSW and RDF obtained by the MBT process is also presented in the paper.

Keywords: compost; $M B T ; R D F / S R F$; waste hierarchy

Fleksibilnost MBO postrojenja

Pregledni članak Mehaničko biološka obrada otpada (MBO) predstavlja niz mehaničkih i bioloških postupaka koji imaju za svrhu smanjiti količinu otpada koji se odlaže na odlagalište što prema "hijerarhiji otpada" definiranoj Direktivom o otpadu (Waste Framework Directive) Europske Unije predstavlja najmanje poželjnu opciju zbrinjavanja otpada. Ulazna komponenta u MBO proces je kruti komunalni otpad (MSW), a izlazne komponente čine RDF gorivo, kompost i eventualno materijali pogodni za recikliranje. Kvaliteta izlaznih komponenti ovisi o ulaznom sastavu otpada. Učinkovito primarno razdvajanje otpada smanjuje potrebu za MBO kapacitetima. RDF nudi mogućnost energetske oporabe dijela izdvojenih frakcija. MBO tehnologije ne rješavaju problem štetnih tvari zaostalih u MSW, koje sužavaju primjenu komposta dobivenog biološkom obradom, a kod spaljivanja RDF-a zahtijevaju dodatne postupke obrade dimnih plinova. U radu je dana usporedba sastava neobrađenog MSW-a i RDF-a dobivenog odabranim MBO postupkom.

Ključne riječi: hijerarhija otpada; kompost; $M B O ; R D F / S R F$

\section{Introduction}

Municipal Solid Waste (MSW) is one of major concerns of modern civilization. Despite huge progress in various technologies of MSW treatment the problem of waste is far from being solved. Developed countries produce more waste but also have higher financial potential for its treatment. Nevertheless, successful waste management is not only the matter of welfare but of approach and choice of proper concept. That gives the chance to the developing and undeveloped countries despite their lower waste treatment funding potential.

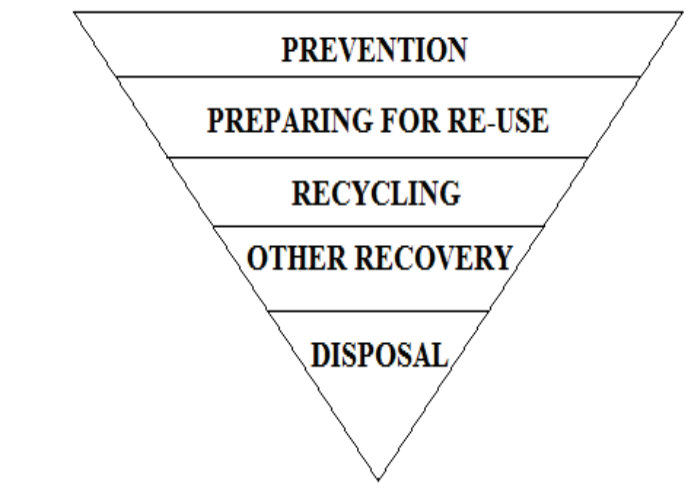

Figure 1 Waste hierarchy according to the EU Waste Framework Directive [1]

Since many ingredients of waste are results of different technologies (packages, used products etc.) they contain certain amount of energy as material (plastic, wood, etc.), also certain amount of energy was used for its production. Having also in mind very complicated nonuniform composition of MSW all waste treatment technologies are dedicated to the same goal of best possible reuse of each ingredient of MSW establishing thesis that waste should not be destroyed but be source of valuable materials and energy. The European Union Waste Framework Directive (2008/98/EC) is dedicated to this concept introducing five step "Waste hierarchy" (Fig. 1). Some further documents reinforced this concept and a few of them are as follows: Circular Economy Package 2.0: Some ideas to complete the circle (European Environmental Bureau, March 2015), Review of the 6th Environment Action Programme and the setting of priorities for the 7th Environment Action Programme (European Parliament resolution of 20 April 2012), General Union Environment Action Programme to 2020: Living well, within the limits of our planet (European Commission, 2014).

The best option is to avoid waste production and the worst option is waste disposal on landfill without any recovery, neither material nor energy [2]. All technologies developed and in use are practically between these two extreme points, including Mechanical Biological Treatment (MBT) of MSW. As stated in [2] "MBT is a residual waste treatment process that involves both mechanical and biological treatment". Also, "MBT therefore compliments, but does not replace, other waste management technologies..."

There are several aims of MBT regarding waste hierarchy and scopes of the EU Landfill Directive (1999/31/EC) [2]:

- pre-treatment of waste going to landfill i.e. decreasing the volume of waste disposed to landfill,

- diversion of biodegradable municipal solid waste (BMW) from non-biodegradable MSW through mechanical sorting ensuring recycling and/or energy recovery through producing refuse derived fuel (RDF), 
- diversion of BMW to be disposed to landfill by reducing dry mass and biodegrability of BMW prior to landfill,

- stabilisation into Compost Like Output (CLO) used as soil improver but with limited application due to contaminating ingredients,

- energy recovery through production of biogas and/or production of high calorific fuel i.e. RDF both for using in combined cycle plants.

In Europe were built many facilities for the treatment of MSW based on MBT $[3 \div 8]$.

\section{Mechanical and biological waste treatment}

In the past, the MSW has mainly been deposited on the landfills.Because of its simplicity, such disposal has a low price, but it is contrary to the order of hierarchy of waste disposal $[9,10]$ and the previously mentioned EU waste management directives and documents. MSW contains mostly organic, biodegradable fraction which occupies $55 \%$ of the total amount of waste [8]. Putrecible ingredients from organic fraction and high moisture content cause in anaerobic conditions on the landfills production of pollutants in the form of leachate and emission of greenhouse gases. If this organic matter is treated in MBT facilities stabilization of the organic matter is achieved [11] and undesirable effects of biological degradation on landfill are avoided. Experiments have shown that anaerobic methane potential $\left(\mathrm{CH}_{4}\right)$ in the non-treated waste amounts from $204 \mathrm{NL}$ $\mathrm{kg}^{-1} \mathrm{dm}[10,12]$ to $250 \mathrm{NL} \mathrm{kg}{ }^{-1} \mathrm{dm}$ (dry matter) [10], while by biological treatment of the same waste in the MBT plant during a period of 28 days, this value is significantly reduced to the value of $57 \mathrm{NL} \mathrm{kg}^{-1} \mathrm{dm}[10$, 11] to140 $\mathrm{NLkg}^{-1} \mathrm{dm}$ [10]. This fact speaks in favour of waste treatment in the MBT facilities, directly contributing to the reduction of biodegradable waste on a landfill according to the Landfill Directive adopted by the European Commission [10, 12, 13, 14].

The reduction of share of the organic fraction in the total amount of waste can be fulfilled in three different ways [10]:

1) Separating the organic fraction on the production site and making of compost.

2) Incinerating MSW in order to produce heat energy and elecricity and

3) Treating MSW in MBT facility to produce stabilized compost that can be disposed at the landfill.

\section{Mechanical - biological waste treatment methods}

Beside separation of biodegradable waste, MBT also increases the amount of other sorts of recycled waste material [14].

MBT facilities use mechanical processing to separate different fractions of municipal solid waste, while by biological treatment the isolated organic fraction is stabilised. Biological treatment is implemented through anaerobic digestion or aerobic composting [14].

MBT facilities are divided into two basic types: Mechanical-Biological Pre-treatment (MBP) and
Mechanical-Biological Stabilization (MBS) processing facilities [15].

MBP plant requires a mechanical-biological pretreatment that includes extraction of the organic fraction and its stabilization prior to disposal on a landfill, and also the process of recycling and the production of RDF fuel.

MBS plant involves biological treatment or stabilization of the total amount of waste with simultaneous separation of materials for recycling and production of RDF. Stabilized residue is disposed on a landfill. The main objective of this process is the production of RDF fraction for heat energy production.

\section{Separation of the organic fraction from the solid municipal waste}

On the territory of EU, during one year, more than 258 million tons of MSW that contains more than $25 \%$ organic matter is produced [11]. To separate organic fraction from the rest of the waste, MSW entering MBT process passes through the process of mechanical separation based on the size of the waste particles.Regardless of the facility type, for the separation of organic material from the rest of the waste a drum sieve separation unit is mainly used as a part of the MBT processing unit (Fig. 2).

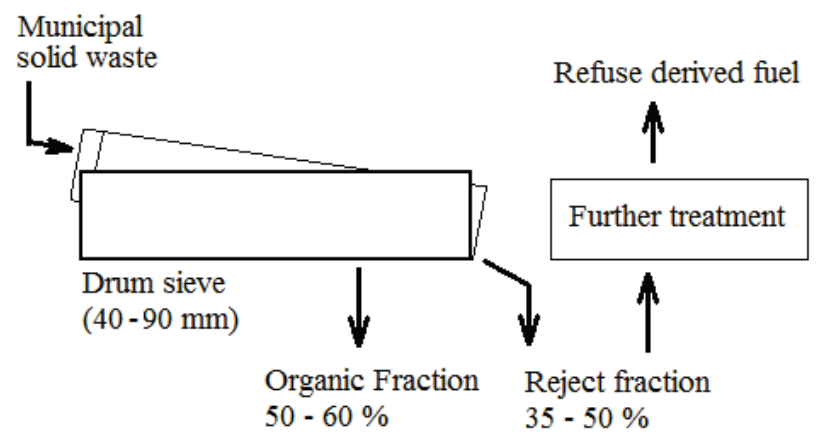

Figure 2 General scheme of the organic fraction separation from the municipal solid waste, based on the physical separation

The average size of the organic fraction particles, which are contained in the solid municipal waste is 8,7 $\mathrm{cm}[11,15]$.The amount of the organic fraction separated from the municipal solid waste depends on the diameter of the holes on the drum sieve. Thus, with a diameter of drum sieve holes of $80 \mathrm{~mm} 63,05 \%$ of the organic fraction is allocated, but with the drum that contains holes of $30 \mathrm{~mm}$ in diameter, $52,6 \%$ of organic fractions are allocated $[11,16]$. The organic fraction used as a raw material for composting may contain undesirable substances often toxic, or ones slowing down the process of composting, both affecting negative the quality of the finished compost [11]. This issue will be discussed later.

\subsection{Processes of the biological treatment of the organic fraction}

In MBT facilities the organic fraction of MSW is biologically processed through anaerobic digestion and/or aerobic composting. Implementation of the aforementioned techniques reduces amount of waste 
disposed to landfills and increases energy and material recovery from the waste.

By an aerobic treatment of the organic fraction the stable fraction ie. compost is obtained, which as the final product can be used to improve the quality of the soil or can be disposed on the landfill without further treatment (Fig. 3a). The anaerobic digestion is the principle of operation of the biogas facilities.This process, as raw material uses organic fraction extracted from MSW. The product obtained in this process is biogas which contains the methane in a significant proportion and can be used in co - generation facilities for heat energy and electricity production.

a)

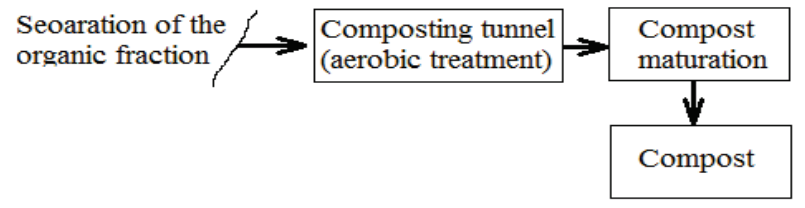

b)

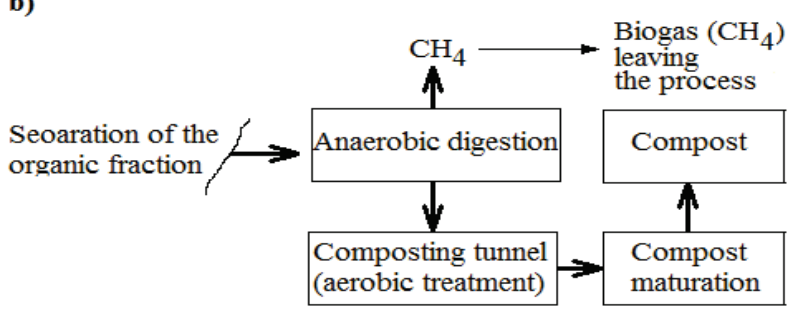

Figure 3 General scheme of the biological treatment process.Figure shows the aerobic (a) and anaerobic (b) treating of the organic fraction

Beside biogas in the process of anaerobic digestion digestate also arise, demanding to be further processed by aerobic composting i.e. by the aerobic treatment process (Fig. 3b) [11, 17].

Potential of methane producing in compost is reduced with the extension of time of composting. The reduced methane potential is important for compost disposal on landfills because stabilized compost does not require further treatment at the landfill, and thus does not impose additional costs. For comparison, the landfill where untreated MSW is disposed requires systems for the degassing and leachate collection, which along with other negative aspects makes such a waste management system completely unacceptable.

As an example the following cases relating to the time of the waste stabilization are presented. Thus, in Italy, the process of bio-stabilisation lasts from 2 to 4 weeks to give a medium stabilized compost [10]. In Austria, Germany and England compost is subjected to the process of bio - stabilisation for a period of 2 to 6 months to give highly stabilized compost, which is then landfilled [10]. Longer process of the bio-stabilization can affect the economics of the process, but results in a more stable product.

\subsection{Undesirable waste products during the organic fraction processing}

\subsubsection{Toxic substances from waste}

By the means of composting is understood the biological decomposition and stabilization of organic substrates under thermophilic conditions that arise as a result of biological activity $[11,18]$. The goal of this process is to obtain final and stable product without pathogenic microorganisms. The MBT plant compost is obtained from the separated organic fraction of MSW which, as already mentioned, can contain undesirable substances that cannot be composted and/or potentially dangerous substances $[11,19]$. Thus obtained and processed, stable compost can be used as a soil conditioner (CLO, Compost-Like Output). However, the use of such products is limited because soluble hazardous substances from compost may be assimilated by plants through the soil, and from the plants get into the human nutrition chain $[11,20 \div 23]$. The most responsible for the contamination are heavy metals from solid waste, from which they have not been completely removed [11].

Analysis of the presence of heavy metals in certain fractions of MSW pointed at high concentrations of cadmium, lead, zinc and chlorine (Tab. 1) due to presence of batteries, electronic waste, shoes, tires, non-packaging plastic and composite materials that have not been separated completely before waste entered MBT process $[24 \div 27]$. It is obvious that equipment used for separation cannot provide waste components containing heavy metals to be fully extracted. Even in the case of a well conducted separation process, the presence of these ingredients cannot be completely excluded. In the case where application of compost for the food production is expected, raw materials from a reliable source have to be used and its input composition must be strictly analysed. Therfore, MSW is far from being appropriate for this purpose.

Table 1 Concentrations of heavy metals in each waste fraction

\begin{tabular}{|l|c|c|c|c|c|}
\hline Waste fraction & $\mathrm{Pb} / \mathrm{mg} / \mathrm{kg}$ & $\mathrm{Cd} / \mathrm{mg} / \mathrm{kg}$ & $\mathrm{Zn} / \mathrm{mg} / \mathrm{kg}$ & $\mathrm{Hg} / \mathrm{mg} / \mathrm{kg}$ & $\mathrm{Cl} / \%$ \\
\hline Ferous metals & 8,6 & 3,1 & 214 & - & - \\
\hline Non-Ferous metals & 59,9 & 3,8 & 30446 & - & - \\
\hline Paper and cardboard & 23 & 0,4 & 424 & 0,08 & 0,5 \\
\hline Glass & 2 & 1 & 50 & - & - \\
\hline Packaging plastics & 109 & 0,9 & 768 & 0,14 & 1 \\
\hline Non packaging films & 219 & 1,3 & 730 & 0,16 & 0,6 \\
\hline Other plastic products & 500 & 67,4 & 4381 & 0,24 & 8,5 \\
\hline Organic waste & 37 & 0,4 & 241 & 0,11 & 0,8 \\
\hline Wood & 105 & 0,9 & 4202 & 0,03 & 0,1 \\
\hline Textiles & 35 & 1 & 520 & 0,15 & 0,4 \\
\hline Shoes & 565 & 23,6 & 2918 & 0,14 & 3,6 \\
\hline Minerals & 350 & 1 & - & - & - \\
\hline Packaging composites & 28 & 0,5 & 204 & 0,02 & 0,5 \\
\hline Electronic waste & 4949 & 328 & 9113 & 3 & 2 \\
\hline Other composite material & 523 & 75 & 6361 & 0,05 & 3,7 \\
\hline Batteries & 135 & 7 & 176668 & 287 & - \\
\hline Leather & 115 & 4,5 & 1296 & 0,68 & 2,7 \\
\hline Rubber & 459 & 11,7 & 14913 & 0,22 & 1,7 \\
\hline Diapers & 36 & 0,2 & 461 & 0,06 & 0,5 \\
\hline Others & - & - & - & - & - \\
\hline Fines $10-40 \mathrm{~mm}$ & 236 & 1,6 & 1274 & 0,27 & 0,3 \\
\hline Fines $<10 \mathrm{~mm}$ & 195 & 1,1 & 10034 & 0,26 & 0,4 \\
\hline
\end{tabular}

For example, the leather found in MSW having lead concentration of $115 \mathrm{mg} / \mathrm{kg}$, per one ton of leather gives $0,11 \mathrm{~kg}$ of lead. This quantity of lead can be released into the environment through the finished compost or through the RDF fuel combustion.

\subsubsection{Undesirable substances in compost}

Paper, plastic and glass residues make majority of undesirable substances in compost lowering its quality. The final stable compost contains one fifth of the 
undesirable substances that negatively interfere composting process [11]. Therefore, the additional treatment of already stable compost is necessary in order to obtain satisfactory quality requiring additional equipment and increasing the cost of the overall production process.

Also, paper, cardboard, plastic and glass pieces make up one third of the total waste [11].This fraction causes overloading of equipment for processing of the organic fraction of municipal solid waste, and a high proportion of paper hinders the composting process due to the high concentration of lignin, the compound present in the newspaper fraction [11, 27]. Lignin is a polymer that is slowly biodegradable and therefore, slows down the whole composting process [11]. On the contrary, the plastic during the composting process behaves inert and provides greater aeration within waste, but if the compost is used as a soil conditioner plastic must be removed before final compost usage [11]. Glass has a similar effect as plastic during the compost treatment. If compost contains about $11 \%$ of glass it can cause a major problem in the final product during use, if not previously removed [11]. Presence of metal at a concentration of $2 \%$ in the compost does not pose any problems during the composting process. During the final processing, the excess traces of metals can be removed [11]. These materials are a valuable source of raw materials for recycling. Plastic contains significant energy potential, while glass and metals have significant potential for recycling.

\section{Waste residues treatment in the MBT plants}

The effectiveness of sorting MSW in the MBT facility depends mostly on the composition and quality of the material that enters the MBT process [24]. Waste separation on the drum sieve separator receives the rough and the fine fractions. The fine fraction is biologically treated because its content of the organic fraction [10], as already discussed. From the remaining rough fraction, if possible materials that can be recycled are separated, and finally the Refuse Derived Fuel (RDF) is produced with the lowest proportion of harmful substances [24]. RDF refers to a general term for a fraction that can be recovered and used as energy source or disposed at the landfill [9]. Within the RDF fraction dominate the components such as paper, plastic, etc. Disposing the $\mathrm{RDF}$ to the landfill does not significantly contribute to reducing the volume of waste on the landfill [8]. However, when the RDF is burned that volume is reduced by $95 \%$ [8]. The most common use of RDF is coincineration in cement kilns where it is used as alternative fuel for cement production and in co-generation plants to produce heat energy and electricity [8, 28]. The fine fraction obtained from the drum sieve, and after that biologically treated, makes $50-60 \%$ of the total municipal solid waste, while the rough fraction makes of $35 \div 50 \%$, both by mass (Tab. 2).

If RDF is co-incinerated, ash containing heavy metals is expected due to existing concentrations of heavy metals in RDF.These concentrations are lower than ones by incineration of MSW [29].
A special category of RDF makes a Solid Recovered Fuel (SRF), which differs from the RDF by the criteria of the heating value, content of mercury and chlorine that are prescribed by the EN standard 15359 and also the CEN / TR 343 standard. SRF categorisation has opened the possibility of trading this type of fuel on market, because mentioned standards established the energy (heating value), technical (chlorine) and ecological (mercury) quality criteria.

\subsection{Comparison of municipal solid waste and RDF fraction}

As stated before important product from MBT plants is RDF fraction that can be used for energy production.

The following text gives an example of a study from which it can be easily seen the benefits when RDF is incinerated instead of MSW [8]. Described MBT plant facility in which the organic fraction was separated from the solid waste using a drum sieve (with the holes of diameter $80 \mathrm{~mm}$ ) is shown in Fig. 4.The separated organic fraction is biologically processed and the remaining waste is mechanically processed to the final product, i.e. the RDF fuel.

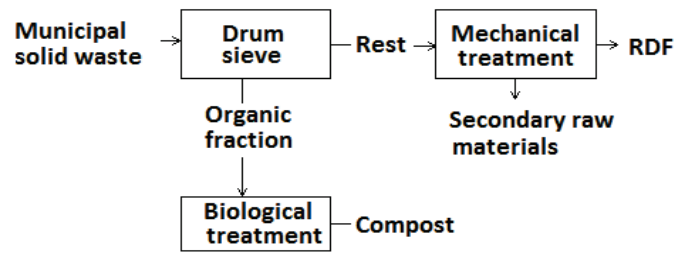

Figure 4 Scheme of MBT plant [8]

The mechanical treatment consists of a manual separation of the recycled waste and magnetic separation of metals.The resulting product of such mechanical processing is RDF fuel that makes $42 \%$ by weight of an input MSW. The composition of the input of MSW and RDF fuel obtained after processing in a MBT plant facility is shown in Tab. 2.

Table 2 Fractions of municipal solid waste and RDF expressed in weight ratios [9]

\begin{tabular}{|l|c|c|}
\hline Waste fraction & MSW / \% & RDF / \% \\
\hline Organic mater & 56,26 & 23,71 \\
\hline Paper and cardboard & 13,8 & 27,91 \\
\hline Plastics & 10,67 & 24,5 \\
\hline HDPE & 0,75 & 0,99 \\
\hline PET & 1,46 & 1,87 \\
\hline LDPE & 5,56 & 10,93 \\
\hline Mix & 2,9 & 10,62 \\
\hline PVC & 0 & 0,08 \\
\hline Glass & 3,28 & 0,48 \\
\hline Ferous metals & 2,46 & 3,1 \\
\hline Non-ferous metals & 0,5 & 0,61 \\
\hline Cellulose & 4,06 & 5,75 \\
\hline Tetrabricks & 1,18 & 2,16 \\
\hline Textiles & 3,57 & 8,65 \\
\hline Wood & 1,33 & 2,18 \\
\hline Rubber & 0,24 & 0,03 \\
\hline Batteries & 0,01 & 0 \\
\hline Garden wastes & 1,84 & 0,14 \\
\hline Electronics & 0,12 & 0,34 \\
\hline Building wastes & 0,69 & 0,48 \\
\hline
\end{tabular}


There is a significant difference in the composition of MSW and RDF, especially regarding the organic fractions, whose content dropped from over half in MSW to approximatelly one fifth in RDF.

The organic fraction in RDF fuel is not desirable because of high share of water which reduces the heating value of fuel. It is clear from Tab. 2 that paper and plastic dominate in RDF content increasing its heating value [8]. However, it is much more appropriate to extract paper and cardboard from the RDF fractions and use them in recycling [30]. Also, as a result of MBT from the input MSW are removed other non-combustible parts such as glass, batteries, garden waste and construction waste.

Some studies suggest that a presence of a higher water content in the RDF composition, beside lowering the heating value, causes the appearance of higher concentrations of harmful gases during combustion, such as $\mathrm{CO}, \mathrm{SO}_{2} \mathrm{NO}$ and $\mathrm{NO}_{2}[8,31]$. However, it can be noted that in the process of mechanical treatment watercontent is reduced by about $50 \%$ [8]. Another important criterion is the ability of waste to burn alone or with the help of additional fuel, when we talk about co-incineration. This criterion is established by Tanner triangle (Fig. 5) which shows that waste can be combusted without additional fuel if its water content is less than $50 \%$, the share of non-combustible substances (ash) is less than $60 \%$, and the proportion of combustible material (carbon C) higher than $25 \%$ [32]. This fact puts burning of RDF far beyond than burning of untreated MSW.

The composition of the non-combustible fractions of waste has to be known, because ash produced in combustion process contains residues of heavy metals such as zinc, cadmium and mercury, demanding proper disposal of ash separated from flue gas.

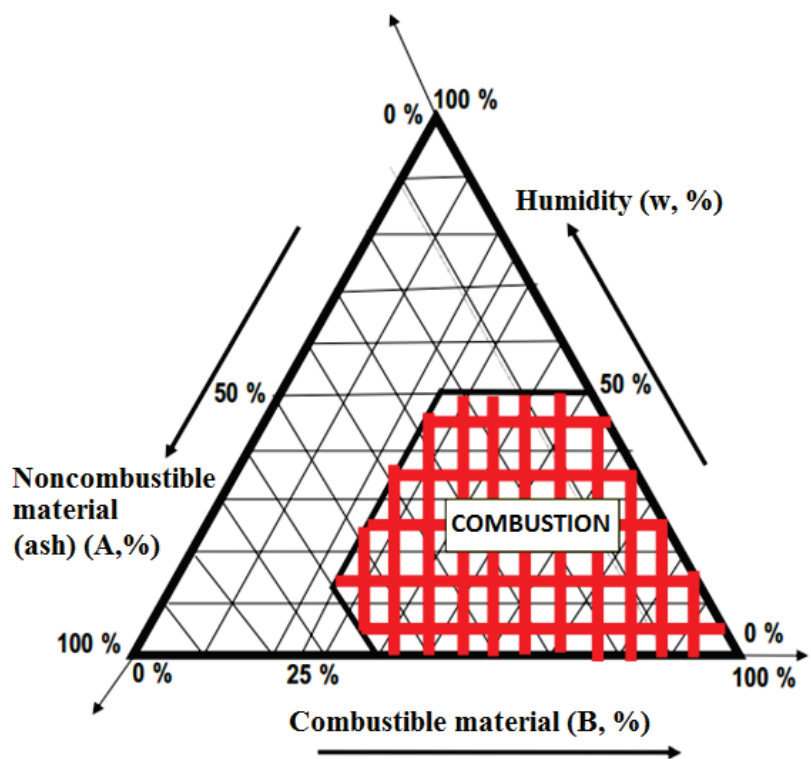

Figure 5 Diagram of Tanner triangle shows minimum conditions for independent fuel burning

RDF produced in previously described MBT process (Fig. 4) contains about $10 \%$ of the non-combustible part i.e. ash, while the MSW contains approximatelly $15 \%$ of non-combustible ingredients [8]. This fact speaks in favour of RDF as fuel instead of untreated MSW [8, 30, 34].
In Tab. 3 is given a proportion of heavy metals in the input MSW, with share of $50 \%$ of organic matter, compost and RDF with a share of $25 \%$ organic matter. The experimental results [8] have shown that the municipal solid waste and RDF fuel, although they differ in heating values, can be both considered as a fuel because their lower energy values exceed $7000 \mathrm{~kJ} / \mathrm{kg}$ [8,34].

The lower heating value of RDF is $16661 \mathrm{~kJ} / \mathrm{kg}$ of $\mathrm{RDF}$, while for MSW it is $8326 \mathrm{~kJ} / \mathrm{kg}$ of waste [8].

Table 3 Overview of the presence of heavy metals in the organic fraction of MSW, compost and RDF fraction

\begin{tabular}{|l|c|c|c|}
\hline Organic fraction within: & $\mathrm{Pb} / \mathrm{g} / \mathrm{t}$ & $\mathrm{Cd} / \mathrm{g} / \mathrm{t}$ & $\mathrm{Hg} / \mathrm{g} / \mathrm{t}$ \\
\hline Municipal solid waste & 18,5 & 0,2 & 0,05 \\
\hline Compost & 16,2 & 0,1 & 0,02 \\
\hline $\mathrm{RDF}$ & 2,3 & 0,1 & 0,03 \\
\hline
\end{tabular}

In the literature, various lower heating values of MSW can be met, such as $8326 \mathrm{~kJ} / \mathrm{kg}$ on Taiwan [8], $2855 \mathrm{~kJ} / \mathrm{kg}$ up to $6710 \mathrm{~kJ} / \mathrm{kg}$ in China [8, 34], $11575 \mathrm{~kJ} / \mathrm{kg}$ in the United States [8, 35], $10600 \mathrm{~kJ} / \mathrm{kg}$ in UK $[9,36]$ and $9999 \mathrm{~kJ} / \mathrm{kg}$ in India [8]. For the RDF, such values are $10110 \mathrm{~kJ} / \mathrm{kg}$ in Italy and $13733 \mathrm{~kJ} / \mathrm{kg}$ for Taiwan [8].The different lower heating values of MSW as well as of RDF are result of their different compositions, especially emphasized heating values of MSW. The higher heating values of RDF fuel, obtained by the described process, have value of about $20583 \mathrm{~kJ} / \mathrm{kg}$ [8, 33].

\section{Conclusion}

MBT is a set of technological operations of waste treatment which can result in various final products and is in accordance with the aims of the waste hierarchy. Concept of the MBT of waste enables selection of the best order of waste processing depending on the input waste composition offering optimal results of the waste processing. Products of MBT vary from RDF/SRF to the stable organic components that can be disposed on landfills or, under certain circumstances, can be used as soil conditioners (CLO). Also, separation and recycling of useful materials is possible, but these materials are not so valuable as they were primary selected.The complexity of the selected MBT technology depends on the input composition of MSW that is a direct consequence of how successful primary selection of waste was. All MBT technologies comply with goals of the waste hierarchy especially minimizing the volume of waste disposed on the landfill. Furthermore, MBT products disposed to landfill do not need any additional treatment since they are already biologically stabilized. RDF/SRF components were also prepared in accordance with the standards for the energy use and are much more suitable for incineration than untreated MSW. Unfortunately, there are problems that any MBT technology of MSW processing does not solve as first the presence of harmful substances, especially heavy metals and presence of recyclable ingredients, both as result of unefficient primary selection of MSW. MBT is a compromise between two extremes, complete primary selection of waste and disposal of untreated MSW to landfill. 


\section{References}

[1] Being wise with waste: the EU's approach to waste management. // Publications Office of the European Union / Luxembourg, 2010.

[2] Department for Environmental Food \& Rural Affairs: Mechanical Biological Treatment of Municipal Solid Waste. // www.defra.gov.uk (27 February 2013)

[3] Bayerd, R.; de Araujo Morais, J.; Ducom, G.; Achour, F.; Rouze, M.; Gourdon, R. Assessment of the effectiveness of an industrial unit of mechanical-biological treatment of municipal solid waste. // Journal of Hazardous Materials. 175, (2010), pp. 23-32. DOI: 10.1016/j.jhazmat.2009.10.049

[4] Barrena, R.; d'Imporzano, G.; Ponsa, S.; Gea T.; Artoa, A.; Vazquez, F.; Sanchez, A.; Adani, F. In search of a reliable technique for the determination of the biological stability of the organic matter in the mechanical-biological treated waste. // Journal of Hazardous Materials. 162, (2009), pp. 1065-1072. DOI: 10.1016/j.jhazmat.2008.05.141

[5] Lornage, R.; Redon, E.; Lagire, T.; Hebe, I.; Carre, J. Performance of a low cost MBT prior to landfilling: study of the biological treatment of size reduced MSW without mechanical sorting. // Waste Management. 27, (2007), pp. 1755-1764. DOI: 10.1016/j.wasman.2006.10.018

[6] Pansa, S.; Gea, T.; Sanchez, A. The effect of storage and mechanical pretreatment on the biological stability of municipal solid waste. // Waste Management. 30, (2010), pp. 441-445. DOI: 10.1016/j.wasman.2009.10.020

[7] Tintner, J.; Smidt, E.; Bohm, K.; Binner, E. Investigation of biological processes in Austrian MBT plants. // Waste Management. 30, (2010), pp. 1903-1907. DOl: 10.1016/j.wasman.2010.06.003

[8] Allen, A. Containment Landfills: the myth of sustainability. // Engineering Geology. 6, (2001), pp 3-19. DOl: 10.1016/S0013-7952(00)00084-3

[9] Montejo, C.; Carlos, C.; Ramos. P.; del Carmen Marquez, M. Analysis and comparison of municipal solid waste and reject fraction as fuels for incineration plants. // Applied Thermal Engineering. 31, (2011), pp. 2135-2140. DOI: 10.1016/j.applthermaleng.2011.03.041

[10] Montejo, C.; Ramos, P.; Costa, C.; Marquez, C. M. Analysis of the presence of improper material in the composting process performed in ten MBT plants. // Bioresurce Technology. 101, (2010), pp. 8267-8272. DOI: 10.1016/j.biortech.2010.06.024

[11] Scaglia, B.; Confalonieri, R.; D'Imporzano, G.; Adani, A. Estimating biogas production of biologically treated municipal waste. // Bioresurce Technology. 101, (2001), pp. 945-952. DOI: 10.1016/j.biortech.2009.08.085

[12] Scaglia, B.; Salatia, S.; Di Gregorio, A.; Carrera, A.; Tambone, F.; Adani, F. Short mechanical biological treatment of municipal solid waste allows landfill impact reduction saving waste energy content. // Bioresurce Technology, 143, (2013), pp. 131-138. DOI 10.1016/j.biortech.2013.05.051

[13] CEC, 1999. Council Directive 1999/31/EC on the landfill of waste. Off. J. Eur. Comunities L 182 (1). Available at: http://www.central2013.eu/fileadmin/user upload/Downloa ds/Document_Centre/OP Resources/Landfill_Directive 19 99_31_EC.pdf (accessed 12.12).

[14] Montejo, C.; Tonini, D.; del Carmen Marquez, M.; Fruergaard Astrup, T. Mechanical - biological treatment: Performance and potentials. An LCA of 8 MBT plants including waste characterization. // Journal of Environmental Management, 128, (2013), pp. 661-673. DOI: 10.1016/j.jenvman.2013.05.063

[15] Tchobanogglous, G.; Theise, H.; Vigil, S. Gestion Integral de Residous Solids. McGraw-Hill, Madrid 1998.

[16] Forster-Carnerio, T.; Perez, M.; Romero, L. I. Thermophilic anaerobic digestion of source-sorted organic fraction of municipal solid waste. // Bioresurce Technology. 99, (2008), pp. 6763-6770. DOI: 10.1016/j.biortech.2008.01.052

[17] Abdullahi, Y. A.; Akunna, J. C.; White, N. A.; Hallett, P. D.; Wheatley, R. Investigating the effects of anaerobic and aerobic post-treatment on quality and stability of organic fraction of municipal solid waste as soil amendment. // Bioresurce Technology. 99, (2008), pp. 8631-8636. DOI: 10.1016/j.biortech.2008.04.027

[18] Haug, R. T. The Practical Handbook of Compost Engineering. CRC Press, Boca Raton, 1993.

[19] Richard, T. L. Municipal solid waste composting: physical and biological processing. // Biomass and Bioenergy. 3, (1992), pp. 163-180. DOI: 10.1016/0961-9534(92)90024-K

[20] Deportes, I.; Benoit-Guyod, J. L.; Zmirou, D. Hazard to man and the environment posed by the use of urban waste compost: a review. // The science of the Total Environment. 172, (1995), pp. 197-222. DOI: 10.1016/0048-9697(95)04808-1

[21] Domingo, J. L.; Nadal, M. Domestic waste composting facilities: a review of human health risk. // Environment International. $35, \quad$ (2009), pp. 382-389. DOI: 10.1016/j.envint.2008.07.004

[22] Shiralipour, A.; McConnel, D. B.; Smith, W. H. Uses and benefits of MSW compost: a review and an assessment. // Biomass and Bioenergy. 3, (1992), pp. 267-279. DOI: 10.1016/0961-9534(92)90031-K

[23] Woodbury, P. B. Trace elements in municipal solid waste compost: a review of potential detrimental effects on plants, soil biota and water quality. // Biomass and Bioenergy. 3, (1992), pp. 239-259. DOI: 10.1016/0961-9534(92)90029-P

[24] Rotter, S. V.; Kost, T.; Winkler, J.; Bilitewski, B. Material flow analysis of RDF - production processes. // Waste Management. 24, (2004), pp. 1005-1021. DOI: 10.1016/j.wasman.2004.07.015

[25] Tamaddon, F.; Hogland, W. Review of Cadmium in Plastic Waste InSwesen. // Waste Management \& Research. 11, (1993), pp. 287-295. DOI: 10.1177/0734242X9301100403

[26] Maystre, L. Y.; Viret, F. A Goal Orientated Characterization of Urban Waste. // Waste Management \& Research. 13, (1995), pp. 207-218. DOI: 10.1177/0734242X9501300303

[27] De Bertoldi, M.; Sequi, P.; Lemmes, B.; Papi, T. The Science of Composting.Blackie Academic and Professional, Glasgow, 1996. DOI: 10.1007/978-94-009-1569-5

[28] Porteous, A. Energy from waste incineration - a state of the art emissions review with an emphasis on public acceptability. // Applied Energy. 70, (2001), pp. 157-167. DOI: 10.1016/S0306-2619(01)00021-6

[29] Chang, Y-H.; Chen, W. C.; Chang, N-B. Comparative evaluation of RDF and MSW incineration. // Journal of Hazardous Materials. 58, (1998), pp. 33-45. DOI: 10.1016/S0304-3894(97)00118-0

[30] Burnley, S.; Philips, R.; Coleman, T.; Rampling, T. Energy implications of the thermal recovery of biodegradable municipal waste materials in the United Kingdom. // Waste Management. $\quad 31, \quad$ (2011), pp 1949-1959. DOI: 10.1016/j.wasman.2011.04.015

[31] Suksankraisorn, K.; Patumsawad, S.; Fungtammasan, B. Co-firing of Thai lignite and municipal solid waste (MSW) in a fluidized bed: effect of MSW moisture content. // Applied Thermal Engineering. 30, (2010), pp. 2693-2627. DOI: 10.1016/j.applthermaleng.2010.07.020

[32] http://www.riteh.uniri.hr/zav katd sluz/zav teh term energ/katedra4/Inzenjerstvo_zastite_okolisa/9.pdf (12.9.2014)

[33] Vignote, S.; Martinez, I. Tecnologia de la madera pp 133, 3a edicion. Mundiprensa, Madrid, 2006.

[34] Liu, Z. Q.; Liu, Z. H.; Li, X. L. Status and prospect of the application of municipal solid waste incineration in China. // Applied Thermal Engineering. 26, (2006), pp. 1193-1197. DOI: 10.1016/j.applthermaleng.2005.07.036 
[35] Tchobanoglous, G.; Theisen, H.; Vigil, S. Integrated solid waste management (Gestion integral de residous). McGraw-Hill, Madrid, 1998.

[36] Porteous, A. Why energy from waste incineration is an essential component of environmentally responsible waste management. // Waste Management. 25, (2005), pp. 451459. DOI: $10.1016 / j$.wasman.2005.02.008

\section{Authors' addresses:}

Bojan Plavac, mag. ing. univ. spec.

University of Zagreb,

Faculty of Chemical Engineering and Technology,

Marulićev trg 19, HR-10000 Zagreb, Croatia

E-mail: bojan.plavac@gmail.com

Igor Sutlović, assoc. prof., Ph.D.

University of Zagreb,

Faculty of Chemical Engineering and Technology,

Savska c. 16, HR-10000 Zagreb, Croatia

E-mail: isutlo@fkit.hr

Veljko Filipan, full. prof., Ph.D.

University of Zagreb,

Faculty of Chemical Engineering and Technology,

Savska c. 16, HR-10000 Zagreb, Croatia

E-mail: vfilipan@fkit.hr 